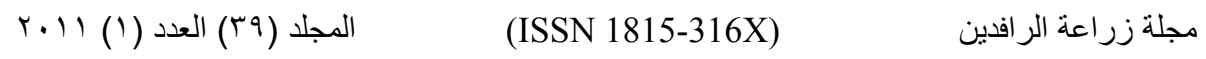

تأثير إضافة مستويات مختلفة من فتامين E لماء الشرب في الأداء الإنتاجي لفروج اللحم.

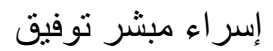

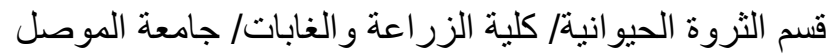

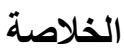

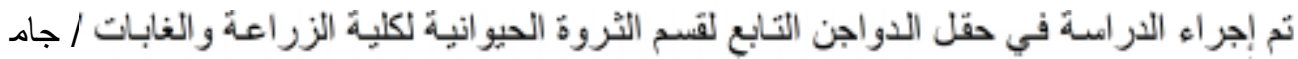

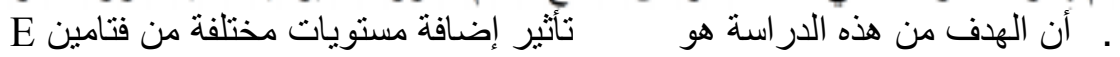

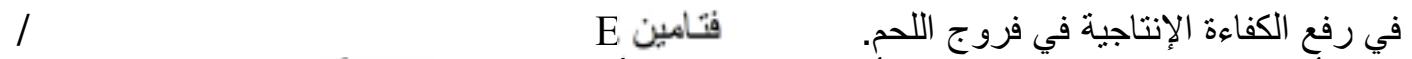

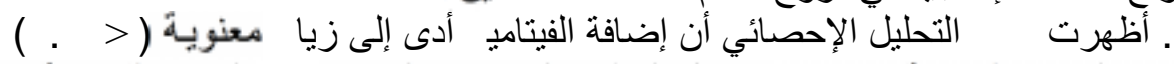

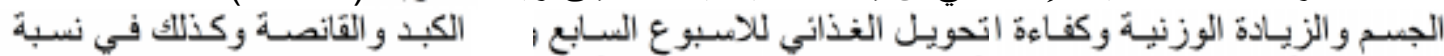

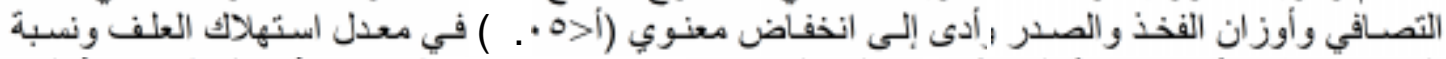

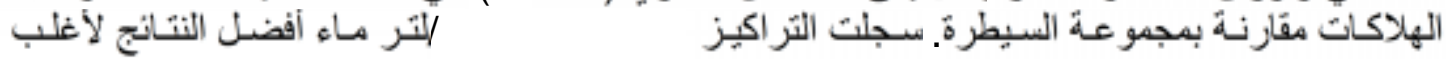

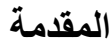

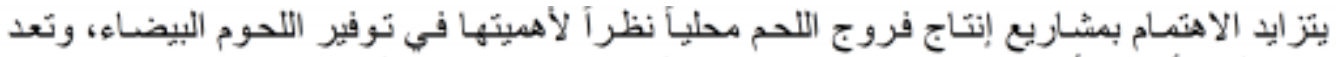

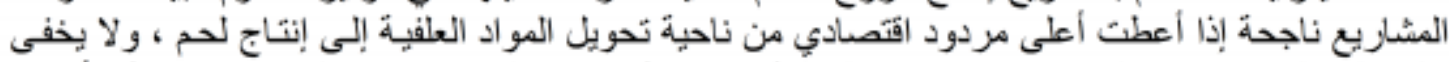

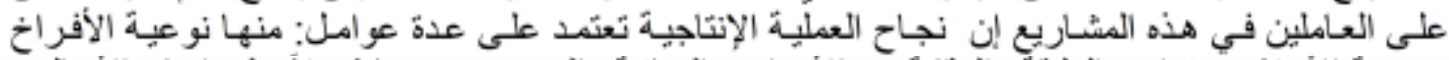

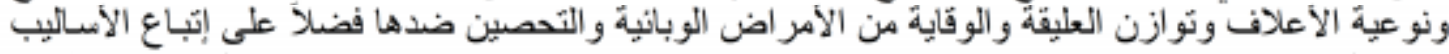

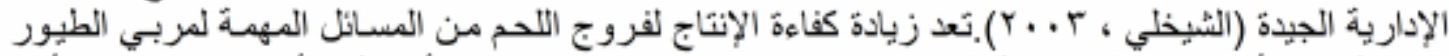

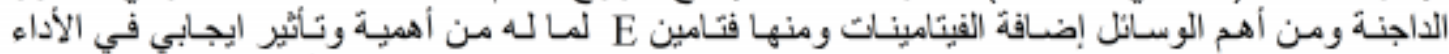

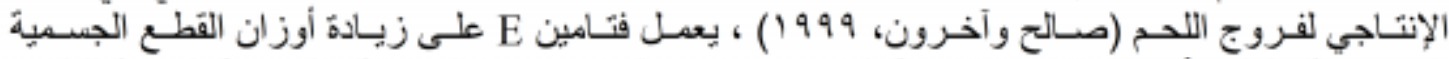

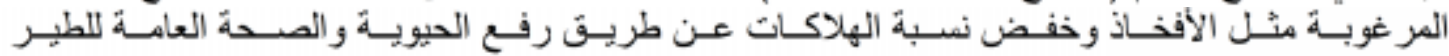

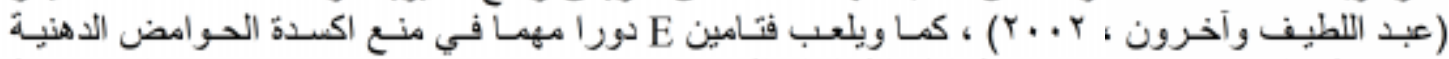

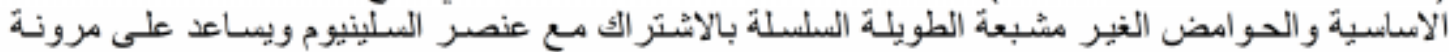

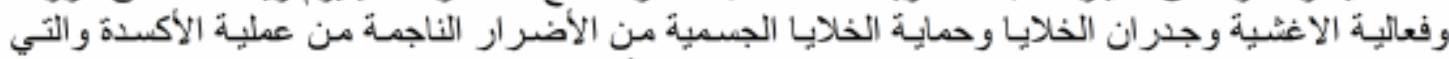

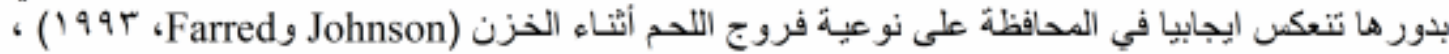

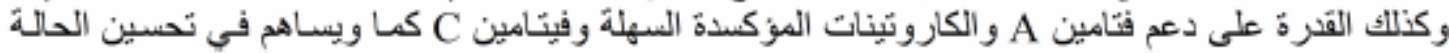

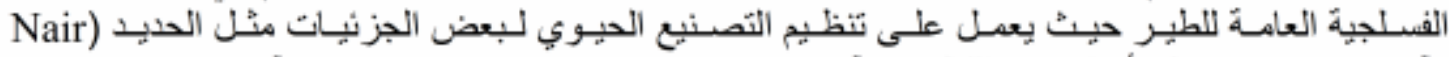
وآخرون،

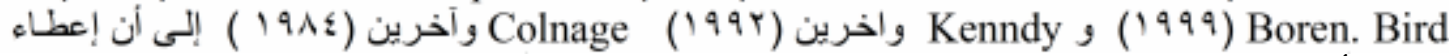

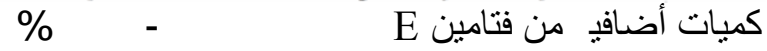

\section{مواد البحث وطرائقه}

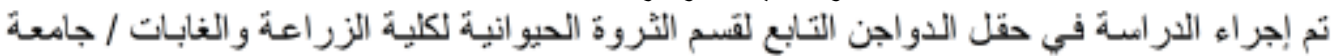

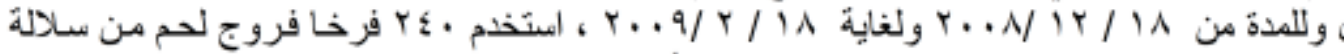

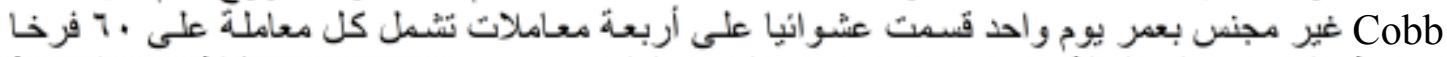

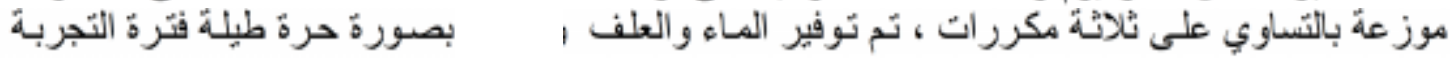

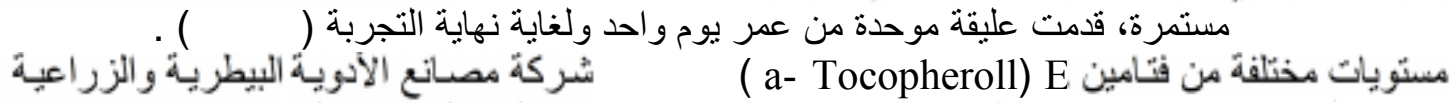

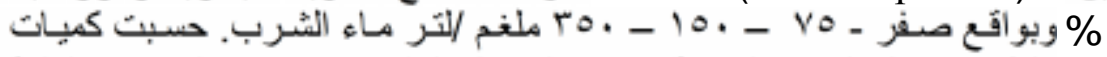

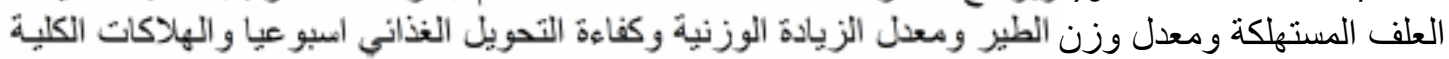

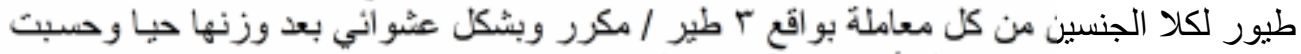

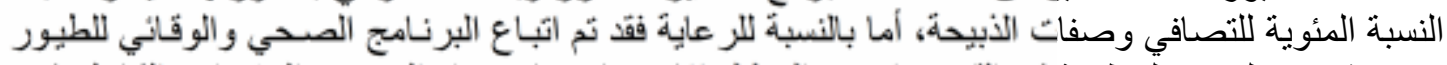

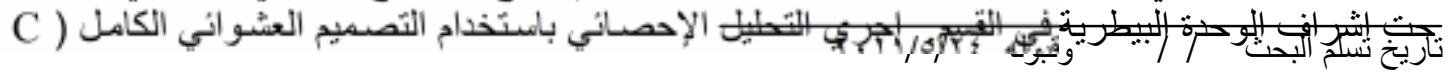



( ) ( )
(ISSN 1815-316X)

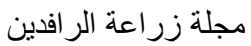

Duncans test . (

قُيـة =Yij Eij
و RD

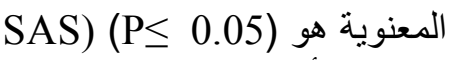
نموذج الرياضي الذي أعتمد عليه في التحليل

$$
\begin{array}{r}
\text { المشاهدات = M } \\
=\text { t i } \\
\text { تأثثنير المعاملة العام للمشاهدات Eij }
\end{array}
$$

\begin{tabular}{|c|c|}
\hline النسبة المئوية & المو اد العلفية \\
\hline \multicolumn{2}{|l|}{. } \\
\hline . & كسبة فول الصويا \\
\hline . & محلية \\
\hline \multicolumn{2}{|l|}{. } \\
\hline & خليط فيتامينات ومعادن واملاح معدنية* \\
\hline \multicolumn{2}{|l|}{. } \\
\hline . & نسبة البروتين \\
\hline \multirow[t]{2}{*}{. } & 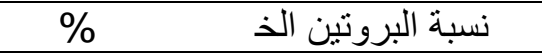 \\
\hline & ( / كيلو ( / \\
\hline
\end{tabular}

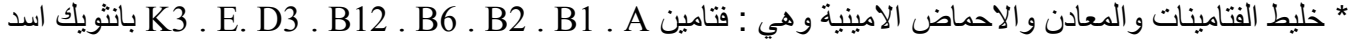

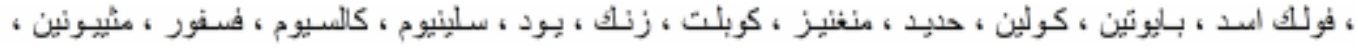

$$
\begin{aligned}
& \text { صوديوم، لايسين }
\end{aligned}
$$

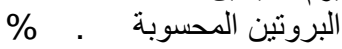

$$
\begin{aligned}
& \text { النتائج والمناقشة }
\end{aligned}
$$

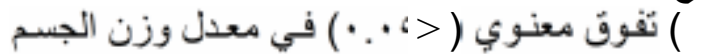

$$
\begin{aligned}
& \text { بينت نتائج التحليِل الإحصـئي(إن }
\end{aligned}
$$

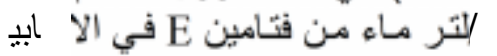

$$
\begin{aligned}
& \text { T4.T3.T2 }
\end{aligned}
$$

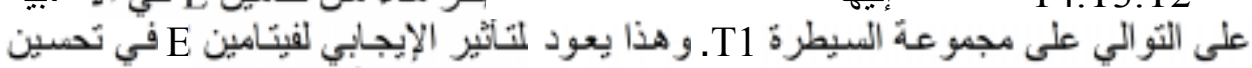

$$
\begin{aligned}
& \text { في حين لم يكن هنالك فرق معنوي بين T3 T3 Tل الأسابيع } \\
& \text { حسابية فقط بين المعاملات لكن }
\end{aligned}
$$

له اله Boa-Amponsem

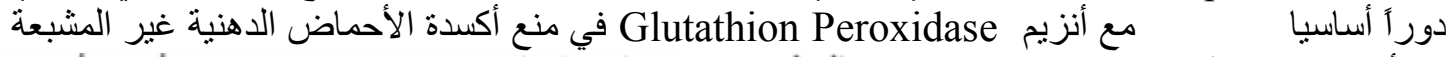

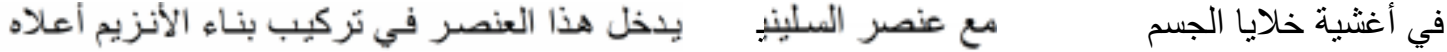

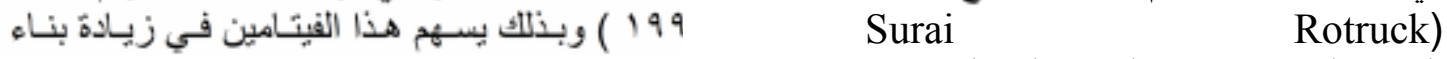
الخلايا الجسمية ومنها الجهاز العضلي.

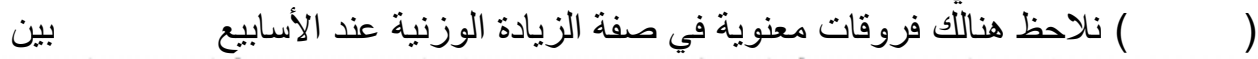

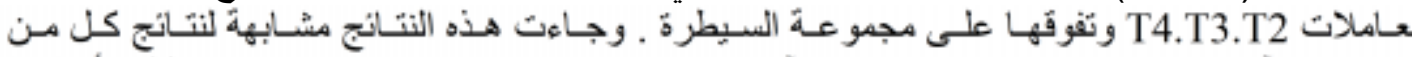

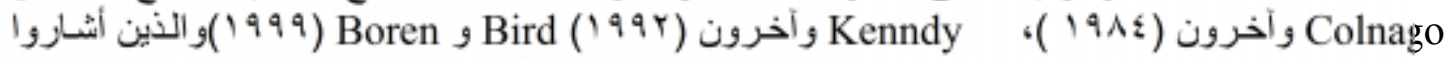

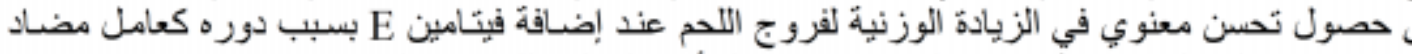

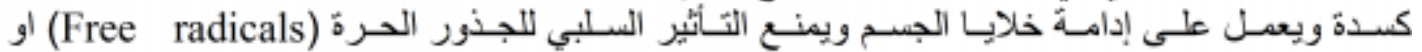

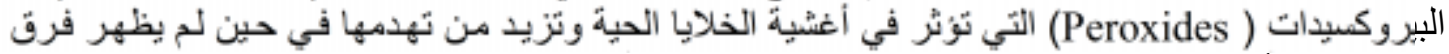




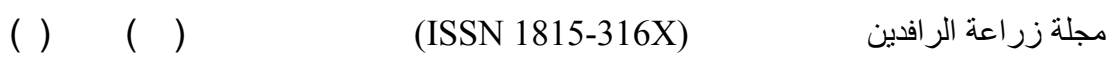

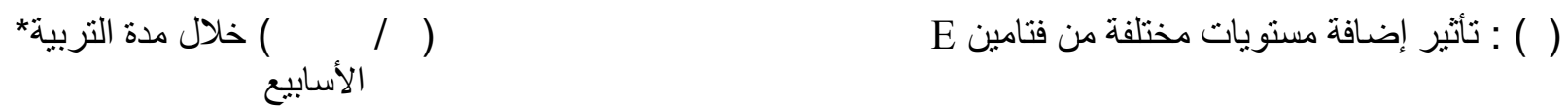

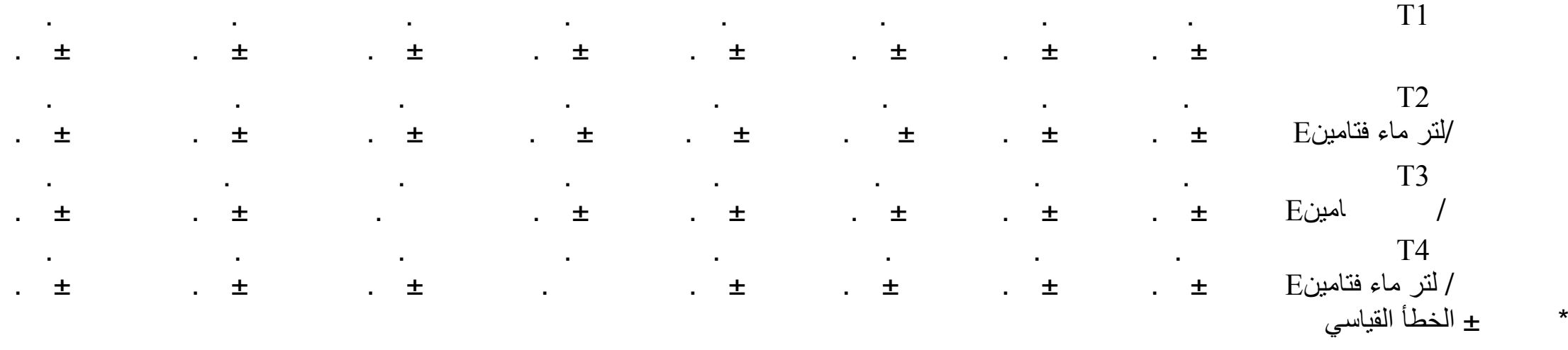

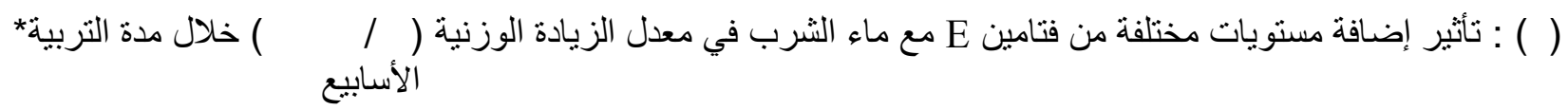

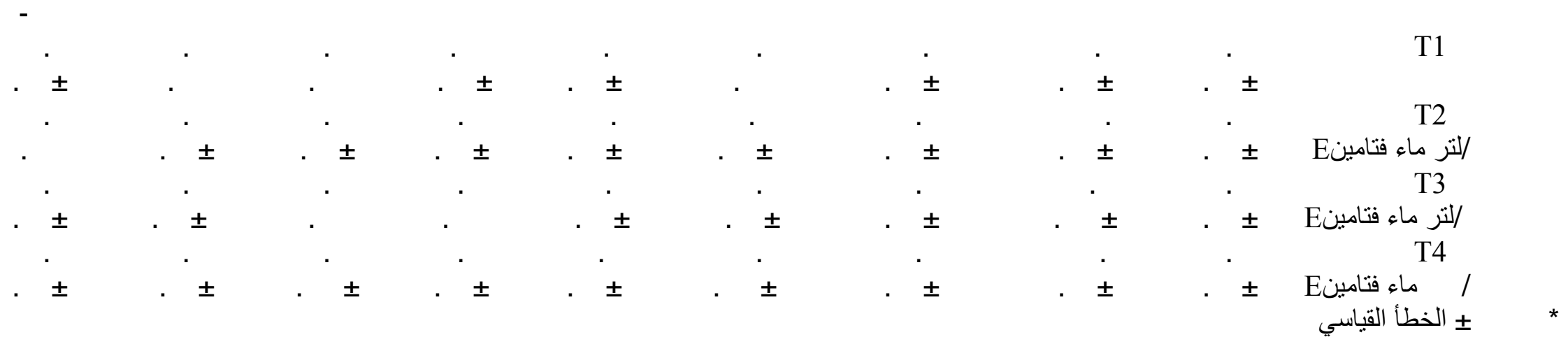




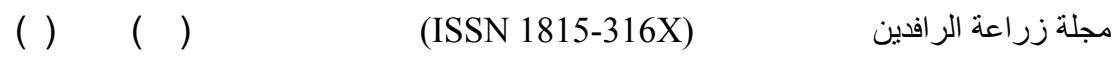

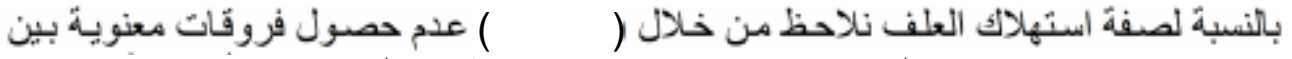

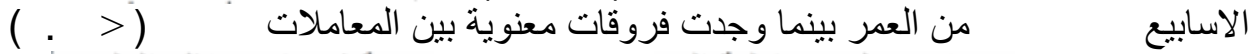
في الأمسابيع

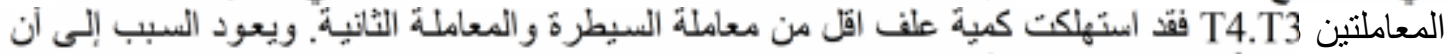

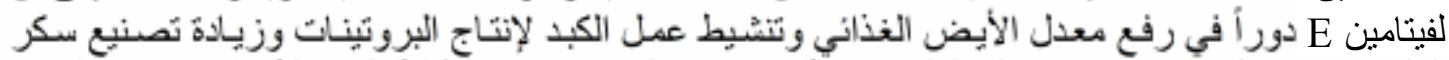

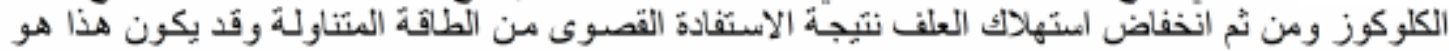

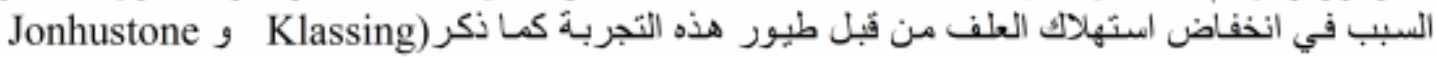

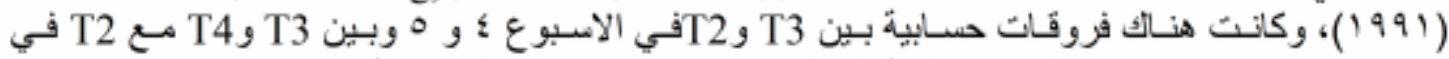

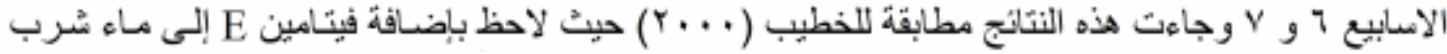
انخفاض في معدل استهلاك

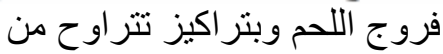

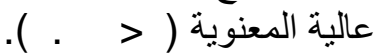

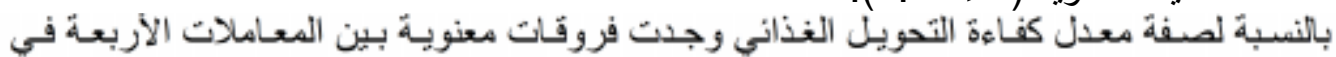

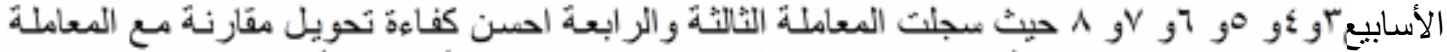

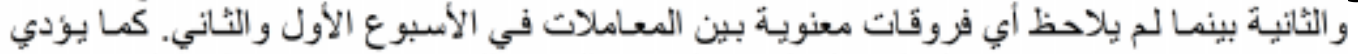

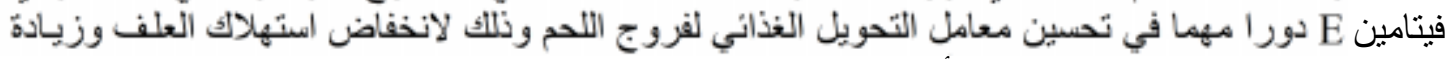

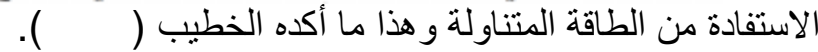

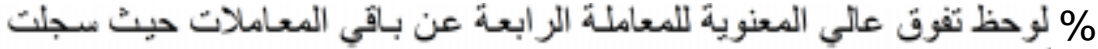

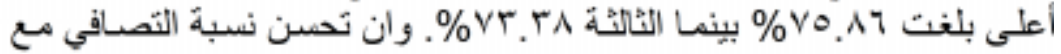

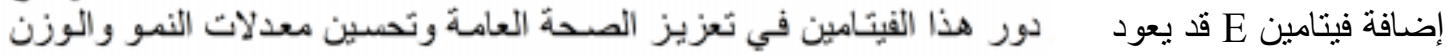

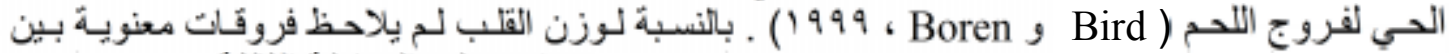
(حيث سجلت المعاملة الثالثنة

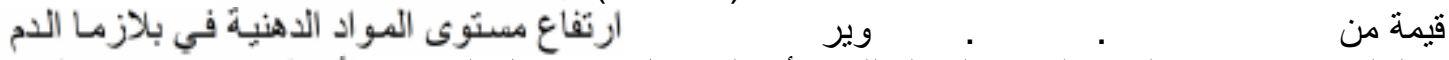

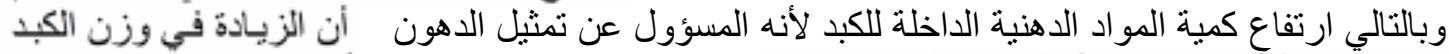

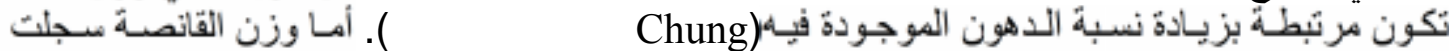

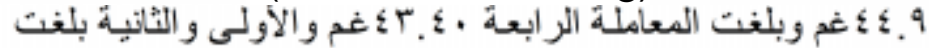

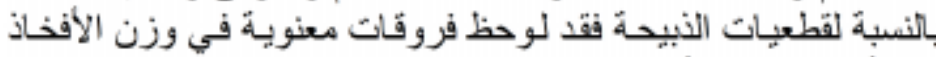

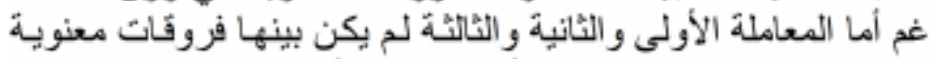

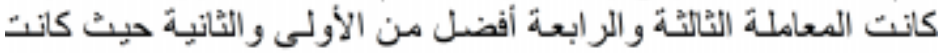

بالنسبة لوزن الظهر T4. T3. T2. T1

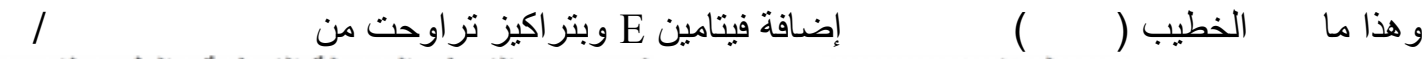

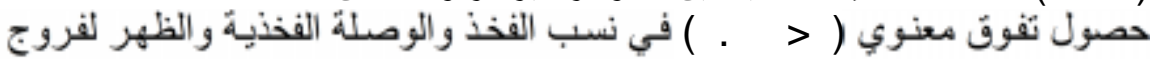

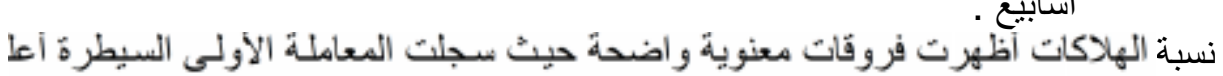

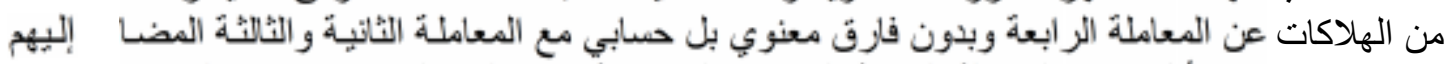

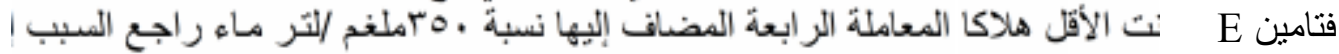

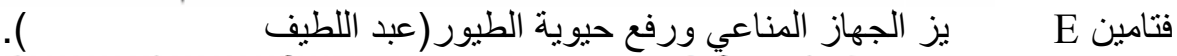

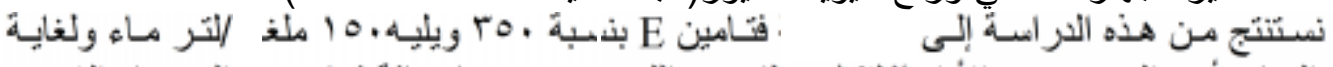

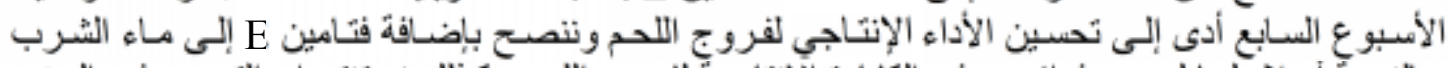

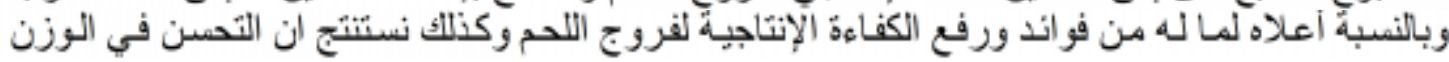

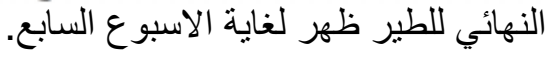



( ) ( )
(ISSN 1815-316X)
مجلة زر اعة الر افدين

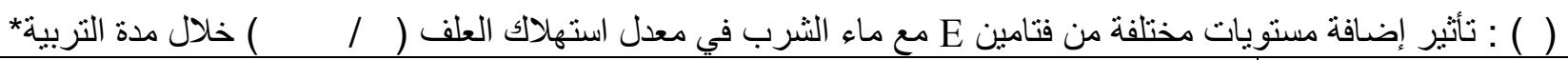

\begin{tabular}{|c|c|c|c|c|c|c|c|c|}
\hline \multicolumn{8}{|c|}{ الأسابي } & \\
\hline . $\quad \pm$ & $\cdot$ &. & . & $\cdot \pm$ & . \pm & $\cdot \pm$ & $\cdot \pm$ & $\mathrm{T} 1$ \\
\hline. & . $\quad \pm$ & . $\quad \pm$ & $. \quad \pm$ & . $\quad \pm$ & . $\quad \pm$ & . & $\cdot \pm$ & 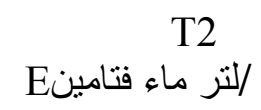 \\
\hline . $\quad \pm$ & $\begin{array}{r}\cdot \\
\pm\end{array}$ & . $\quad \pm$ & . & . $\quad$. & . $\quad \pm$ & . & $\cdot \pm$ & /لتر ماء فتامينE \\
\hline . & . & . & . & $\cdot \pm$ & $\cdot \pm$ & $\cdot \pm$ & $\cdot \pm$ & 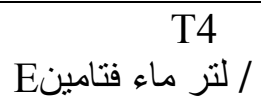 \\
\hline
\end{tabular}

\begin{tabular}{|c|c|c|c|c|c|c|c|c|}
\hline \multicolumn{3}{|c|}{ / غم زيادة وزنية ) خلال مدة التربية* } & \multicolumn{4}{|c|}{ ب في معدل كفاءة التحويل الغذائي ( } & \multicolumn{2}{|c|}{ لـ إضـافة مستو يات مختلفة من فتامين E } \\
\hline \multicolumn{8}{|c|}{ الأسابيع } & \\
\hline$\cdot \quad \pm$ & $\cdot \pm$ & $\cdot$ & $\cdot \pm$ & $\cdot \quad \pm$ & $\cdot \pm$ & $\cdot \pm$ & $\cdot \pm$ & $\mathrm{T} 1$ \\
\hline$\cdot \pm$ & $\cdot \pm$ & $\cdot \pm$ & $\cdot \pm$ & . $\quad \pm$ & . $\quad \pm$ & . \pm & . \pm & /لتر ماء فتامين \\
\hline$\cdot \quad \pm$ & $\cdot \pm$ & $\cdot \pm$ & . $\quad \pm$ & . \pm & & $\cdot \pm$ & . \pm & /لتر ماء فتامينE \\
\hline$\cdot \quad \pm$ & $\cdot \pm$ & $\cdot \quad \pm$ & $\cdot \pm$ & . \pm & . \pm & $\cdot \pm$ & $\cdot \pm$ & 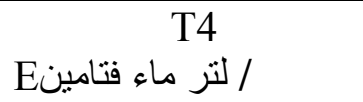 \\
\hline
\end{tabular}



( ) ( )
(ISSN 1815-316X)
مجلة زر اعة الر افدين

ل نسبة التصافي و الهلاكات ووزن وصفات الذبيحة خلال مدة التربية

E ( ) تأثثر إضافة مستويات مختلفة من فتامين

\begin{tabular}{|c|c|c|c|c|c|c|c|c|}
\hline $\begin{array}{c}\text { نسبة الهلاكات } \\
\text { \% }\end{array}$ & () & وزن الظهر & ( ) & () & () & () & $\%$ & \\
\hline$\cdot \pm$ &. & . \pm & . $\quad \pm$ & $\cdot \pm$ & $\cdot \pm$ & $\cdot \pm$ & $\cdot \dot{ }$ & $\mathrm{T} 1$ \\
\hline$\cdot$. & $\cdot \pm$ & . &. & $\cdot \pm$ & $\cdot \pm$ & $\cdot \pm$ & $\cdot \pm$ & /لتر ماء فتامينE \\
\hline. & $\cdot \pm$ & . & . & $\cdot \pm$ & $\cdot \pm$ & $\cdot \pm$ &. & 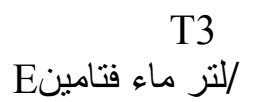 \\
\hline$\cdot \pm$ & \pm &. & . \pm & . \pm & . \pm & . \pm & . \pm & $\begin{array}{c}\mathrm{T} 4 \\
\text { / لتر ماء فتامين }\end{array}$ \\
\hline
\end{tabular}



( ) ( )
(ISSN 1815-316X)
مجلة زر اعة الر افدين

\title{
EFFECT OF SUPPLEMENTATION OF DIFFREINT LEVELS OF VITAMIN E WITH DRINKING WATER ON PRODUCTIVE PERFORMANCE OF BROILER
}

Esraa Mobasher Tawfeek

Collage of Agri. and Forestry. Univ. of Mosul.Iraq

\begin{abstract}
This experiment was conducted at Animal Production Department Farm /College of Agriculture. University of Mosul.. to study the effect of adding different levels of vitamin $\mathrm{E}(0.75 .150$ and 350$) \mathrm{mg} /$ liter to drinking water on productive performance of broiler. The data showed that the addition of vit. E resulted in significant increase $(\mathrm{P}<0.05)$ in body weight. weight gain. feed conversion ratio in the 7 week . weight of liver and dressing percentage . weight of thigh. breast. The result revealed that supplementation of vitamin E significantly $(\mathrm{P}<0.05)$ decreased feed intake and mortality in comparison with control group. It was concluded that vitamin $\mathrm{E}$ at the rate of 150 to $350 \mathrm{mg} /$ liter of drinking water surpassed other levels with regards to the characteristics measured surpassed on productive performance and immune resporse of broiler.
\end{abstract}

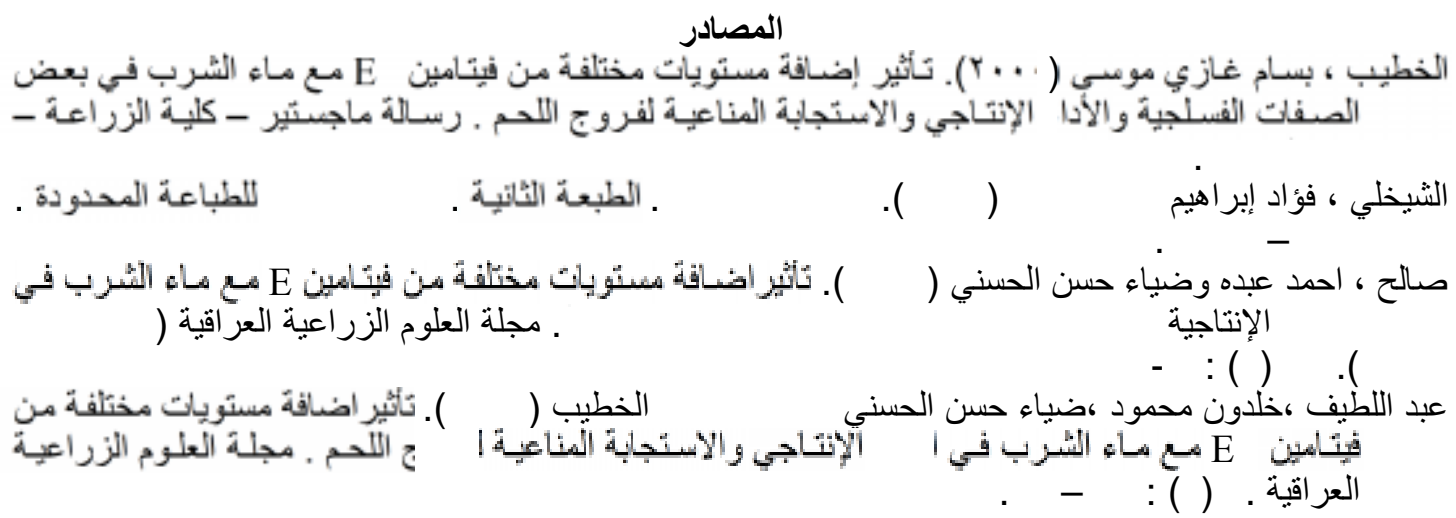

Bird. J. N. . and B. Boren (1999). Vitamin E and immunity in commercial broiler production. World Poultry Sci. 15:20-22

Boa-Amponsem. K. . S. E. H. Price. P. A.Gerart. and P. B. Siegel (2000). Vitamin E and immue Responses of broiler pureline chickens. Poultry Sci. 79: 466-476.

Chung. R. A. . J. C. Rogler. and W. J. Stadelman (1965). The effect of dietary cholesterol and deferent dietary fats on cholesterol content and lipid composition of egg yolk and various body tissue Poultry Sci: 44: 221-228.

Colnago. G. L. . L. S. Jensen. and P. L. long (1984). Effect of selenium and vitamin E on the development of immunity of coccidiosis in chicks. Poultry Sci. 63: 1136-1143.

Johnson. R.J. and D. J.Farrel(1993) Advances in the role of Micro-Nutrients in Livestock production. Recent Advances in Animal Nutrition In Australia:239-253.

Kennedy. D. G. . D. A. Rice. D. W. Bruce. E. A. Goodall. and S. G. Mellroy (1992). Economic effects of increased vitamin $\mathrm{E}$ supplementation of broiler diet on commercial broiler production. Bri. Poultry Sci. 33: 1015-1023.

Klassing. K. C. and B. J. Jonhustone(1991). Mono Kines in growth and development. Poultry Sci. 70: 1781-1789.

Nair. P. P. (1972). Vitamin E and metabolic regulation. Ann. N. Y. Acad. Sci.. 203: 53.

Rotruck. J. T.. A. L. Pope. H. E. Ganther. A. B. Swanson. D. G. Haferuan. and W. G. Hockstral (1973). Selenium biochemical role as a component of glutathion peroxidase. Science. 1979: 588.

SAS. 1992. Statistical Analysis System. SAS institute Inc.. cory. Nc.

Surai. p. F.. E. Kutz. G. J. Washart. R. C. Nobel. and K. Speake (1997). The relationship between the dietary provision of $\alpha$ - tocopherol and the concentration of this vitamin $\mathrm{E}$ in the semen of chicken: effect on lipid composition and susceptibility to peroxidation Reprod. Fert. 110: 47-51. 